10IKC-118

\title{
CARBONATED ECLOGITE AT 3.5-5.5 GPA- THE EFFECT OF THE CAPSULE MATERIAL ON SOLIDUS TEMPERATURES
}

\author{
Kiseeva $^{1}$ ES, Yaxley ${ }^{1}$ GM, Kamenetsky ${ }^{2}$ VS \\ ${ }^{1}$ The Australian National University, Canberra, ACT, 0200, Australia \\ ${ }^{2}$ Centre for Ore Deposit Research and School of Earth Sciences, University of Tasmania, Hobart, Tasmania 7001, Australia
}

We experimentally investigated a nominally anhydrous, K-bearing, altered MORB composition $\mathrm{GA} 1+10 \% \mathrm{CaCO}_{3}(\mathrm{GA} 1 \mathrm{cc})$, from $1050-1400^{\circ} \mathrm{C}$ and 3.5-5.5 GPa. This composition (see Table in the abstract 10IKC-081) models deep subduction of carbonated oceanic crust, the major process for replenishment of the earth's deep carbon cycle. All experiments were conducted in $1.27 \mathrm{~cm}$ diameter end-loaded BoydEngland type piston-cylinder apparatuses in the Research School of Earth Sciences, The Australian National University with two types of capsules: "Pt with inner graphite (Pt-Gr)" and "Au-Pd". A 200 ton press was employed for the experiments at 3.5 and $4.5 \mathrm{GPa}$, while for 5 and $5.5 \mathrm{GPa}$ experiments an ultrahigh pressure 500 ton pistoncylinder press was used.

The observed phase assemblages were used to construct an experimental P-T phase diagram (Fig. 1).

The subsolidus phase assemblages for both sets of experiments (Pt-Gr and Au-Pd) consist of clinopyroxene, garnet, carbonate, rutile, $\mathrm{K}$ Feldspar, coesite (at 4.5 and 5.0 GPa) and apatite (observed only in the Pt-Gr subsolidus run). The textures observed in the experiments change dramatically with the degree of melting. Abovesolidus experiments contain quenched partial melts which differ in two sets of runs. In Pt-Gr runs the partial melts can be subdivided into four types. With increasing temperature at any given pressure they are: low-degree siliceous melts,

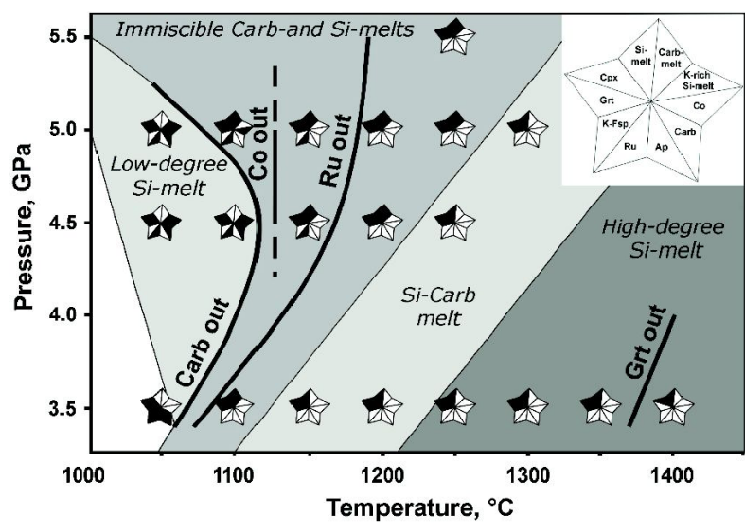

Figure 1. Experimental P-T phase diagram for GA1cc in Pt-Gr capsules. Si-melt - silicate melt, Carb-melt carbonate melt, Si-Carb melt - silicate-carbonate melt, Carb - solid carbonate, $\mathrm{Co}$ - coesite, $\mathrm{Ru}$ - rutile, Grt - garnet, Cpx - clinopyroxene, Ap - apatite, K-Fsp - K-feldspar. Krich Si-melt (in the legend) is identical in composition to the field of the Low-degree Si-melt on the diagram.

coexisting silicate and carbonate melts, silicatecarbonate melts and high-degree silicate melts. In $\mathrm{Au}-\mathrm{Pd}$ runs the melts evolve from low-degree carbonatitic to siliceous at higher degrees of melting.

\section{MELTING CHARACTER IN NOMINALLY ANHYDROUS EXPERIMENTS IN A PT-GR CAPSULE}

Melts exhibit various textures and compositions depending on the degree of melting. Low-degree siliceous melts were detected only 


\section{$1^{\text {th }}$ International Kimberlite Conference, Bangalore - 2012}

in runs at 4.5 and $5.0 \mathrm{GPa}$ at $1050-1100^{\circ} \mathrm{C}$ and $1050^{\circ} \mathrm{C}$ respectively. Such melt quenches into small patches of homogenous glass and either occupies a small region around and within the carbon spheres or is non-uniformly distributed throughout the run material. These melts have low totals (80-90\%) and high content of silica and potassium (roughly $58-60$ wt. $\% \mathrm{SiO}_{2}$ and $9-11 \%$ $\mathrm{K}_{2} \mathrm{O}$ ), which made them similar to $\mathrm{K}$-feldspar composition.

Two coexisting carbonate and silicate melts (Fig. 2a-d) were observed at all pressures at lowintermediate degrees of melting. The temperature interval of two coexisting melts expands with pressure and varies from around $50^{\circ} \mathrm{C}$ at $3.5 \mathrm{GPa}$ to around $150^{\circ} \mathrm{C}$ at $5.0 \mathrm{GPa}$. This corresponds to only one run at $1100^{\circ} \mathrm{C}$ at $3.5 \mathrm{GPa}$, two runs 1150 and $1200^{\circ} \mathrm{C}$ at $4.5 \mathrm{GPa}$ and four runs 1100 $1250^{\circ} \mathrm{C}$ at $5.0 \mathrm{GPa}$. The only run at $5.5 \mathrm{GPa}$ and $1250^{\circ} \mathrm{C}$ also produced two coexisting liquids.

The two coexisting melts can either form separate pools within a carbon sphere (Fig. 2a-d), or be interstitial to the residual silicate grains on the edge of the capsule with higher degrees of melting. Carbonate-immiscible melt forms
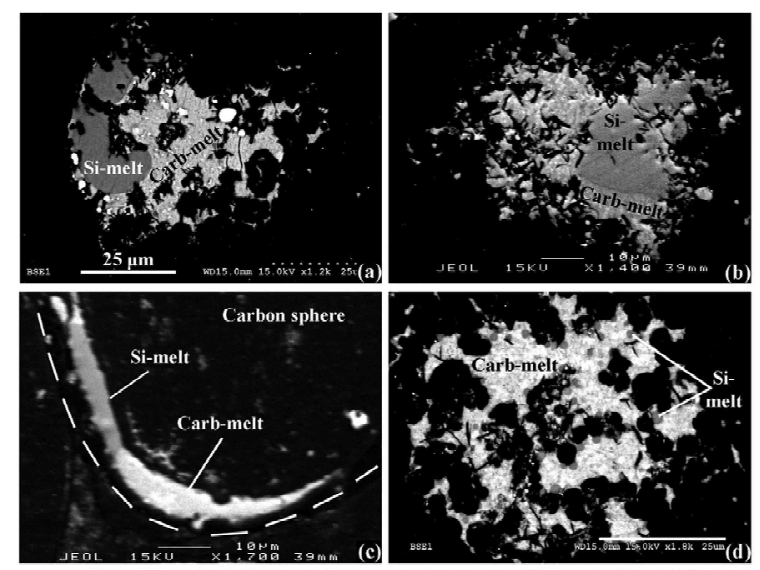

Figure 2. BSE images of the immiscible melts (IM): silicate (dark grey) and carbonate (light grey). (a) Run G1150_4.5 (should be read as $\mathrm{GA} 1 \mathrm{cc}$ at $1150^{\circ} \mathrm{C}$ and $4.5 \mathrm{GPa}$ ) and (b) Run G1150_5. IM within carbon sphere. Bright crystals are quenched Ru. (c) Run G1100_5. IM around the carbon sphere. (d) Run G1100_3.5. Small round ocelli of silicate melt inside the pool of carbonate melt inside the carbon sphere. irregular shapes and is usually heterogeneous and patchy compared to the subsolidus carbonate crystals formed at lower temperatures.

The proportion of carbonate and silicate melts within the heterogeneous area can differ significantly. If a random melt pocket composed of silicate and carbonate liquids is considered, then any of the following scenarios can be applied: silicate melt $>$ carbonate melt, carbonate melt $>$ silicate melt (Fig. 2d), and approximately equal amounts of both melts (Fig. 2b). With the increase of temperature at the same pressure, the amount of silicate melt pools increases.

The two coexisting melts, present at temperatures above the low-degree alkali-rich siliceous melting field always exhibit carbonate and silicate compositions. Although the carbonate melts seem to be similar in composition to solid carbonate, they can be clearly distinguished from it. First, the melts have much lower Mg\# and lower $\mathrm{Ca}$. Also, the addition of minor elements is very useful for the distinction as the carbonate melts have high Ti, $\mathrm{P}$ and $\mathrm{K}$ contents (up to $3.98 \mathrm{wt} . \%$ $\mathrm{TiO}_{2}, 1.46$ wt. $\% \mathrm{Na}_{2} \mathrm{O}, 3.30$ wt. $\% \mathrm{P}_{2} \mathrm{O}_{5}$ and 3.00 wt. $\% \mathrm{~K}_{2} \mathrm{O}$ ), whereas in the subsolidus carbonate these elements are much less abundant (often below detection limits).

The SEM-EDS totals of carbonate immiscible melts are very low (about 55-65\%), because of the large amount of carbonate component. In some cases small grains of quenched apatite are present within the melt. All calcitic carbonate melts have fairly high $\mathrm{Fe}$ and $\mathrm{Mg}$ contents (5.83-9.72 wt.\% $\mathrm{FeO}$ and 3.02-4.73 wt. $\% \mathrm{MgO}) . \mathrm{SiO}_{2}$ contents can vary within a wide range (from 0.59 to $17.5 \mathrm{wt} \% \mathrm{SiO}_{2}$ ) and tend to increase with increasing temperature. At higher temperatures the carbonate and silicate melt compositions approach each other and the proportion of silicate melt increases.

The coexisting silicate melts display significantly higher microprobe totals than coexisting carbonate-rich melts (75-90 wt.\%). These melts are usually K-rich (2.67-10.2 wt.\% 


\section{$1^{\text {th }}$ International Kimberlite Conference, Bangalore - 2012}

$\mathrm{K}_{2} \mathrm{O}$ ) and resemble the compositions of lowdegree siliceous melts. However, with increasing temperature, the silicate melts become less potassic and more magnesian and calcic. The $\mathrm{Fe}$ and $\mathrm{Mg}$ contents of these melts are less than in coexisting carbonate melts, while $\mathrm{Na}_{2} \mathrm{O}$ is higher. Summarizing the compositions of coexisting carbonate and silicate melts: $\mathrm{K}, \mathrm{Al}$ and to a lesser extent $\mathrm{Na}$ tend to be concentrated in silicate melts; whereas $\mathrm{P}, \mathrm{Mg}, \mathrm{Fe}, \mathrm{Ca}$ are incorporated into the carbonate melts. Mn partitions into garnet and is present in all the melts in very low abundances.

Immiscible liquids in the experiments show regular compositional trends with increasing temperature (Fig. 3). The data obtained in this study are in very good agreement with all the other data on alkali-poor carbonated eclogites, although compared to the other studies, silicate and carbonate immiscible melts at lower temperatures in GA1cc are very strongly shifted toward the $\mathrm{Si}+\mathrm{Al}$ and $\mathrm{Ca}+\mathrm{Mg}+\mathrm{Fe}$ apices at Figure 3.

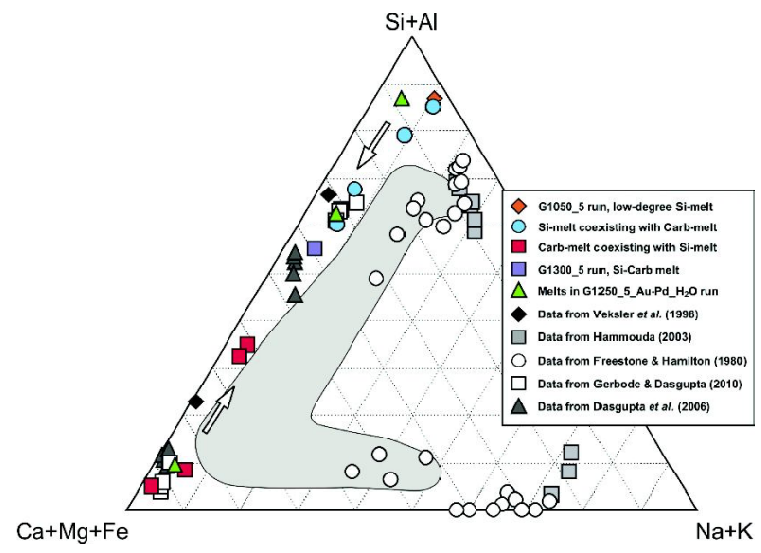

Figure 3. Immiscible melts compositions in this and other studies. Black symbols indicate compositions obtained in this study for the experimental runs in Pt-Gr capsule at $5 \mathrm{GPa}$ : diamond - low-degree K-rich melt, circles - immiscible silicate melts, squares - immiscible carbonate melts, crossed square - silicate-carbonate melt, triangle IM in G1250_5_Au-Pd_ $\mathrm{H}_{2} \mathrm{O}$ run. Colourless symbols represent the compositions of IM obtained in other studies. Grey area represents the field of Cl-poor fluid and melt inclusions from Siberian pipes after Zedgenizov et al. (2010). Arrows show the change in melt compositions in this study with increasing temperature. All the elements are given in moles, molar $\left(\mathrm{SiO}_{2}+\mathrm{Al}_{2} \mathrm{O}_{3}\right)$, molar $(\mathrm{CaO}+\mathrm{MgO}+\mathrm{FeO})$, molar $\left(\mathrm{Na}_{2} \mathrm{O}+\mathrm{K}_{2} \mathrm{O}\right)$. Data from Freestone \& Hamilton (1980), Veksler et al. (1998), Hammouda (2003), Dasgupta et al. (2006), Gerbode \& Dasgupta (2010), Kiseeva et al. (2011)..
Silicate-carbonate melts were detected at intermediate degrees of melting at all pressures. They occur in two runs at 1150 and $1200^{\circ} \mathrm{C}$ at 3.5 $\mathrm{GPa}$, in one run at $1250^{\circ} \mathrm{C}$ at $4.5 \mathrm{GPa}$ and in one run at $1300^{\circ} \mathrm{C}$ and $5.0 \mathrm{GPa}$. Tiny (5 ìm) fragments of silicate-carbonate melts tend to be spread randomly in small, isolated patches throughout the capsule (Fig. 4). The interpretation of this texture is that initially the melt contained rather high amounts of dissolved volatile components, presumably mostly $\mathrm{CO}_{2}$ or carbonate $(>30-40$ wt.\%). Upon quenching, $\mathrm{CO}_{2}$ separated from the silicate liquid and dispersed the melt throughout significant volumes of the graphite capsule. The polishing of these sorts of runs was particularly difficult due to the resulting vesiculation and fragmentation of graphite capsules.



Figure 4. BSE image of experimental run G1200_3.5. (a) Silicatecarbonate melt spread throughout the capsule. Mineral phases are Grt and Cpx. (b) enlargement of image area shown in (a).

To check this hypothesis, a capsule-piercing procedure while determining the outcome using gas chromatography was undertaken. The G1200_3.5 run was reproduced. The capsule was pierced post-run under vacuum into a gas chromatograph and the spectrum revealed a $\mathrm{CO}_{2}$ peak, consistent with the above interpretation. No $\mathrm{H}_{2} \mathrm{O}$ peak was detected, although some $\mathrm{H}_{2} \mathrm{O}$ may be present dissolved in the quenched melts.

It is inferred therefore that all the other melts that formed between the liquid immiscibility field and distinctly separated silicate melts pools, produced $\mathrm{CO}_{2}$ fluid on quenching. Therefore compositionally these dispersed melts are defined as silicate-carbonate. The definition is used 


\section{$1^{\text {th }}$ International Kimberlite Conference, Bangalore - 2012}

because melts contain significant amount of both silicate and carbonate components.

High-degree silicate melts were observed only at $3.5 \mathrm{GPa}$ at high and very high degrees of melting, which corresponds to the temperatures higher than $1250^{\circ} \mathrm{C}$. These melts quench to separate pool of quenched glass at one end of the capsule (Fig. 5) and are inferred to contain significant dissolved $\mathrm{CO}_{2}(<12 \%$, based on mass balance calculations and the EDS analysis totals).



Fig. 5. BSE image of experimental run G1350_3.5. Melt pool and mineral phases segregated to different parts of the capsule.

\section{MELTING CHARACTER IN NOMINALLY ANHYDROUS EXPERIMENTS IN AAU-PD CAPSULE}

Five additional experiments at $5 \mathrm{GPa}$ with the identical starting composition and temperatures to the $5 \mathrm{GPa}$ Pt-Gr experiments, were performed in $\mathrm{Au}-\mathrm{Pd}$ capsules with no inner graphite. The run at $1200^{\circ} \mathrm{C}$ crystallized a subsolidus phase assemblage, with clinopyroxene, garnet, rutile, calcitic carbonate, coesite and $\mathrm{K}$ feldspar. No melt was detected. At this pressure, the estimated solidus based on the $\mathrm{Pt}-\mathrm{Gr}$ encapsulated runs is below $1050^{\circ} \mathrm{C}$. Therefore an apparent $200^{\circ} \mathrm{C}$ increase in solidus temperature is observed in the Au-Pd encapsulated experiment relative to the $\mathrm{Pt}-\mathrm{Gr}$ experiment. First melt appeared at $1225^{\circ} \mathrm{C}$ and was of carbonatitic composition. This melt has a heterogenous texture and contains quenched carbonate and other crystals. At this temperature no more solid carbonate or K-feldspar was detected, although tiny $(<1$ ìm) K- and Al-rich patches were occasionally observed along garnet-clinopyroxene grain boundaries. Their fine grain size precluded accurate determination of their composition. Although the possibility that they are residual Kfeldspar crystals is not ruled out, it is suggested that they are more likely to be metastable K-rich phases quenched from the K-rich carbonatitic melt.

With an increase in the degree of melting, no liquid immiscibility was detected and melts evolved towards more siliceous compositions.

\section{MELTING CHARACTER IN HYDROUS EXPERIMENT IN A AU-PD CAPSULE}

One experiment was performed with the addition of free water. The run conditions were $1250^{\circ} \mathrm{C}$ at $5.0 \mathrm{GPa}$ with about 10 wt. $\% \mathrm{H}_{2} \mathrm{O}$ estimated.

There are three distinct melts in the G1250_5_Au-Pd_H $\mathrm{H}_{2} \mathrm{O}$ run: carbonate and silicate immiscible melts which occur interstitial to mineral phases (Fig. 6), and a high fraction of silicate melt, which occupies about half of the capsule. The formation of high-degree silicatemelt is accounted for by the thermal gradient and is due to the large capsule length. On the other hand, it allows the comparison of immiscible and high-degree silicate melts. Because of the small size of the pocket with two immiscible melts, it is not possible to obtain the precise composition for some elements $(\mathrm{Ca}, \mathrm{Mg}$ for silicate immiscible melt and Si for carbonate-immiscible melt). Nevertheless, these melts follow the general trend of the melt evolution with temperature in Pt-Gr experiments. Thus, this experiment confirms that low-degree silicate-rich melt and coexistence of immiscible silicate-rich and carbonate-rich melts at higher degree of melting in the Pt-Gr 


\section{$10^{\text {th }}$ International Kimberlite Conference, Bangalore - 2012}



Figure 6. Figure 2.3. BSE images of the IM: Run G1250_5_Au$\mathrm{Pd}_{-} \mathrm{H}_{2} \mathrm{O}$. IM pool within the crystalline grains of Grt.

experiments are probably explained by unavoidable contamination of the sample by the penetration of $\mathrm{H}_{2} \mathrm{O}$ or hydrogen.

Thus, the most striking results from this study are (1) the differences in near solidus melts between the experiments conducted using the different capsule materials (potassic siliceous melt in Pt-Gr versus carbonatite melt in Au-Pd) and (2) the significant difference of approximately $130^{\circ} \mathrm{C}$ between the estimated carbonate solidus temperatures at $5.0 \mathrm{GPa}$ in experiments conducted using Pt-Gr capsules and those using Au-Pd capsules. Further the possible reasons for these contrasting melting behaviours are explored.

Although extensive efforts were made to minimize hydration of mixes and experimental components during preparation of the assemblies, it is likely that during the relatively long-duration runs, hydrogen diffused into the $\mathrm{Pt}$ capsules and produced $\mathrm{H}_{2} \mathrm{O}$ (Brooker et al., 1998) by reaction with $\mathrm{CO}_{2}$ or $\mathrm{FeO}$. To test this hypothesis FTIR spectrometry was applied and 0.87 wt. $\% \mathrm{H}_{2} \mathrm{O}$ in the quenched glass from run G1400_3.5 was measured, which suggests presence of about 0.5 wt. $\% \mathrm{H}_{2} \mathrm{O}$ in the experiments. In order to minimise the effect of hydrogen penetration into the capsule and hydration of the sample, experiments were made in Au-Pd capsules. Au-Pd capsules permit less $\mathrm{H}$ diffusion than $\mathrm{Pt}$ under experimental conditions (Hall et al., 2004; Nishihara et al., 2006). The dramatic difference between the results in two different capsules with GA1cc apparently indicates either different permeability of $\mathrm{Pt}$ and $\mathrm{Au}-\mathrm{Pd}$ for $\mathrm{H}$ or possible redox reactions caused by the presence of graphite in the Pt capsules. Elevated permeability of $\mathrm{Pt}$ capsule has also been observed by Laporte et al. (2004).

Thus, the silicate solidus temperature at any investigated pressure for the $\mathrm{Pt}-\mathrm{Gr}$ capsule experiments is one of an infinite array of $\mathrm{H}_{2} \mathrm{O}$ undersaturated solidi, which decrease in temperature with increasing $\mathrm{H}_{2} \mathrm{O}$ content from the inferred anhydrous GA1cc carbonate solidus (the $\mathrm{Au}-\mathrm{Pd}$ experiments) towards the $\mathrm{H}_{2} \mathrm{O}$-saturated solidus of GA1cc as determined by Yaxley \& Green (1994).

This assumption has been proved by the experiment in a Au-Pd capsule with deliberately added $\mathrm{H}_{2} \mathrm{O}$, in which two immiscible carbonate and silicate melts were formed at $5 \mathrm{GPa}$ and $1250^{\circ} \mathrm{C}$ and the degree of melting was near $50 \%$. This demonstrates that liquid immiscibility for GAlcc composition at 3.5-5.0 GPa is valid only for the high $\mathrm{H}_{2} \mathrm{O} / \mathrm{CO}_{2}(\sim \mathrm{e} " 0.1)$ ratios in the system.

Although many studies have proved the depression of the eclogitic silicate solidus under hydrous conditions, to author's knowledge, the current study is the first demonstration that the carbonate solidus under the influence of minor amounts of water in the system is also lowered in temperature. This can have a major impact on melting relations of carbonate eclogite inferred to be present in the mantle.

\section{CONCLUSIONS}

1) Based on the comparison between solidus temperatures and subduction geotherms the $\mathrm{H}_{2} \mathrm{O}$-undersaturated carbonated eclogite would survive along typical subduction P-T paths without melting.

2) Both silicate and carbonate solidi of carbonate- 


\section{$1^{\text {th }}$ International Kimberlite Conference, Bangalore - 2012}

bearing $\mathrm{H}_{2} \mathrm{O}$-undersaturated eclogite within cratonic pressures are at lower temperatures than the wet-solidus of a peridotite. According to average mantle geotherm, at $5 \mathrm{GPa}$ carbonate-bearing $\mathrm{H}_{2} \mathrm{O}$-undesaturated eclogite will not survive equilibration with mantle temperatures and will start melting.

3) The lowest-degree melts for $\mathrm{H}_{2} \mathrm{O}$ undersaturated carbonate-bearing MORB compositions at 3.5-5.0 GPa are K-rich highly siliceous liquids (broadly trachyandesitephonolite), which have not yet been reported in any previous experimental studies of carbonate eclogites.

4) Liquid immiscibility is a result of the presence of minor $\mathrm{H}_{2} \mathrm{O}$ in the system. It was observed at all the pressures in a narrow melting interval (13-18\%) and over a temperature interval expanding with pressure from about $50^{\circ} \mathrm{C}$ at $3.5 \mathrm{GPa}$ to $>150^{\circ} \mathrm{C}$ at $5 \mathrm{GPa}$.

5) Intermediate- to high-degree melts for both anhydrous and $\mathrm{H}_{2} \mathrm{O}$-saturated compositions are Si-undersaturated silicate-carbonate melts (3645 wt. $\% \mathrm{SiO}_{2}$ ) containing substantial dissolved $\mathrm{CO}_{2}$ (up to about $21 \% \mathrm{CO}_{2}$ ).

6) In contrast to previous reports, the $\mathrm{SiO}_{2}$ content of the melt can decrease with increasing degree of melting. This occurs in $\mathrm{H}_{2} \mathrm{O}$-undersaturated systems all the way through to until the closure of the immiscibility gap and can explain the variation of fluid and melt inclusions in $\mathrm{Cl}$ free (or Cl-poor) diamonds.

\section{Bibliography}

Brooker, R., Holloway, J. R. \& Hervig, R. (1998). Reduction in piston-cylinder experiments: the detection of carbon infiltration into platinum capsules. American Mineralogist 83, 985-994.

Dasgupta, R., Hirschmann, M. M. \& Stalker, K. (2006). Immiscible transition from carbonate-rich to silicate-rich melts in the $3 \mathrm{GPa}$ melting interval of eclogite $+\mathrm{CO}_{2}$ and genesis of silica-undersaturated ocean island lavas. Journal of Petrology 47, 647671.

Freestone, I. C. \& Hamilton, D. L. (1980). The role of liquid immiscibility in the genesis of carbonatites - an experimental study. Contributions to Mineralogy and Petrology 73, 105-117.

Gerbode, C. \& Dasgupta, R. (2010). Carbonate-fluxed melting of MORB-like pyroxenite at $2.9 \mathrm{GPa}$ and genesis of HIMU ocean island basalts. Journal of Petrology 51, 2067-2088.

Hall, L. J., Brodie, J., Wood, B. J. \& Carroll, M. R. (2004). Iron and water losses from hydrous basalts contained in $\mathrm{Au}_{80} \mathrm{Pd}_{20}$ capsules at high pressure and temperature. Mineralogical Magazine 68, 75-81.

Hammouda, T. (2003). High-pressure melting of carbonated eclogite and experimental constraints on carbon recycling and storage in the mantle. Earth and Planetary Science Letters 214, 357-368.

Kiseeva, E. S., Yaxley, G. M., Hermann, J., Litasov, K. D., Rosenthal, A. \& Kamenetsky, V. S. (2011). An experimental study of carbonated eclogite at 3.5-5.5 GPa - implications for silicate and carbonate metasomatism in the cratonic mantle. Journal of Petrology (accepted).

Laporte, D., Toplis, M. J., Seyler, M. \& Devidal, J. L. (2004). A new experimental technique for extracting liquids from peridotite at very low degrees of melting: application to partial melting of depleted peridotite. Contributions to Mineralogy and Petrology 146, 463-484.

Nishihara, Y., Shinmei, T. \& Karato, S. (2006). Graingrowth kinetics in wadsleyite: effects of chemical environment. Physics of The Earth and Planetary Interiors 154, 30-43.

Veksler, I. V., Petibon, C., Jenner, G. A., Dorfman, A. M. \& Dingwell, D. B. (1998). Trace element partitioning in immiscible silicate-carbonate liquid systems: an initial experimental study using a centrifuge autoclave. Journal of Petrology 39, 2095-2104.

Yaxley, G. M. \& Green, D. H. (1994). Experimental demonstration of refractory carbonate-bearing eclogite and siliceous melt in the subduction regime. Earth and Planetary Science Letters 128, 313-325. 